\title{
Determination of Ascorbic Acid, Acetaminophen, and Caffeine in Urine, Blood Serum by Electrochemical Sensor Based on $\mathrm{ZnO}-\mathrm{Zn}_{2} \mathrm{SnO}_{4}-\mathrm{SnO}_{2}$ Nanocomposite and Graphene
}

\author{
Elham Nikpanje, Manochehr Bahmaei*, and Amirabdolah Mehrdad Sharif \\ Department of Analytical Chemistry, Faculty of Chemistry, Islamic Azad University, North Tehran Branch, Tehran, Iran
}

\begin{abstract}
In the present research, a simple electrochemical sensor based on a carbon paste electrode (CPE) modified with $\mathrm{ZnO}$ $\mathrm{Zn}_{2} \mathrm{SnO}_{4}-\mathrm{SnO}_{2}$ and graphene $\left(\mathrm{ZnO}-\mathrm{Zn}_{2} \mathrm{SnO}_{4}-\mathrm{SnO}_{2} / \mathrm{Gr} / \mathrm{CPE}\right)$ was developed for the direct, simultaneous and individual electrochemical measurement of Acetaminophen (AC), Caffeine (Caf) and Ascorbic acid (AA). The synthesized nanomaterials were investigated using scanning electron microscopy, X-ray Diffraction, Fourier-transform infrared spectroscopy, and electrochemical impedance spectroscopy techniques. Cyclic voltammetry and differential pulse voltammetry were applied for electrochemical investigation $\mathrm{ZnO}_{-} \mathrm{Zn}_{2} \mathrm{SnO}_{4}-\mathrm{SnO}_{2} / \mathrm{Gr} / \mathrm{CPE}$, and the impact of scan rate and the concentration of $\mathrm{H}^{+}$on the electrode's responses were investigated. The voltammograms showed a linear relationship between the response of the electrode for individual oxidation of AA, AC and, Caf in the range of 0.021-120, 0.018-85.3, and 0.02$97.51 \mu \mathrm{M}$ with the detection limit of $8.94,6.66$ and $7.09 \mathrm{nM}(\mathrm{S} / \mathrm{N}=3)$, respectively. Also, the amperometric technique was applied for the measuring of the target molecules in the range of 0.013-16, 0.008-12 and, 0.01-14 $\mu \mathrm{M}$ for $\mathrm{AA}, \mathrm{AC}$ and, Caf with the detection limit of $6.28,3.64$ and $3.85 \mathrm{nM}$, respectively. Besides, the $\mathrm{ZnO}-\mathrm{Zn}_{2} \mathrm{SnO}_{4}-\mathrm{SnO} / \mathrm{Gr} / \mathrm{CPE}$ shows an excellent selectivity, stability, repeatability, and reproducibility for the determination of AA, AC and, Caf. Finally, the proposed sensor was successfully used to show the amount of AA, AC and, Caf in urine, blood serum samples with recoveries ranging between $95.8 \%$ and $104.06 \%$.
\end{abstract}

Keywords : Determination, Caffeine, Blood Serum, Voltammetry, $\mathrm{ZnO}_{-} \mathrm{Zn}_{2} \mathrm{SnO}_{4}-\mathrm{SnO}_{2}$

Received : 8 January 2020, Accepted : 26 June 2020

\section{Introduction}

Acetaminophen (AC) or paracetamol is known as a safe analgesic and antipyretic drug since 1953 to treat fever, cold, cough and, pain. However, the impressment mechanism of AC is still debated. It has been assumed that $\mathrm{AC}$ activates descending serotonergic pathways which leads to inhibition of prostaglandin synthesis [1]. Although AC is considered as a safe painkiller, with minimal side effects, severe poisonings such as liver failure and kidney damage have been reported due to excessive consumption of prescribed doses [2]. So it is crucial that the level of AC must determine in biological human body fluid.

*E-mail address: M_bahmaei@iau-tnb.ac.ir

DOI: https://doi.org/10.33961/jecst.2020.00724

This is an open-access article distributed under the terms of the Creative Commons Attribution Non-Commercial License (http://creativecommons.org/licenses/by-nc/4.0) which permits unrestricted non-commercial use, distribution, and reproduction in any medium, provided the original work is properly cited.
Caffeine (Caf) as a naturally occurring alkaloid, which is the most widely devoured psychoactive substance, can be founded in some plant-based products and beverages. Depending on some factors such as the taken dosage, the bodyweight, and individual response, Caf has several impacts on the consumer [3]. For example, it can increase the ability for mental activity and muscular work [4]. Also, it has antioxidant activity [5]. Other effects of Caf are stimulating the central nervous system, gastric acid secretion, increasing blood pressure, nausea, seizures, anxiety, diuresis, trembling and, nervousness. Some research has been reported that the adverse effect of Caf on DNA [6] and also a high dosage of this molecule on the human body can increase the probability of cardiovascular diseases. Caf is used for the treatment of some diseases, for example asthma, headache, and nasal congestion [7].

One of the essential vitamins for the synthesis of 
neurotransmitters, muscle carnitine and also collagen is and, Ascorbic acid (AA). AA is a water-soluble vitamin, which the human body is not capable of synthesizing it. However, due to the numerous advantages of this substance, AA must be in our diet [8]. This vitamin act as an antioxidant and has a considerable role in normal neuronal physiology and neuromodulator in the brain. Some illnesses can be prevented or treated by AA such as cold, AIDS, infertility and, even cancers or mental illnesses. Despite the mentioned advantages, a high dosage of AA can lead to gastrointestinal disturbances or diarrhea [9].

However, AC, Caf and, AA often occur together in certain drug formulations; a small amount of research has been carried out on the simultaneous detection of these biomolecules. Drugs consisting of AC and Caf combinations are frequently used as pain relief, central nervous system stimulant and, an analgesic agent. On the other hand, one obstacle in the simultaneous electrochemical monitoring of AA and AC is overlapping their oxidation peaks at the surface of traditional electrodes. Also, in some spectrophotometric and titrimetric methods, the interference of AA is serious for the determination of AC. To overcome these problems, design of a simple, rapid, sensitive, selective and inexpensive electrochemical method based on a modified electrode is necessary which could be used for the simultaneous measurement of $\mathrm{AC}, \mathrm{Caf}$ and, AA $[4,10,11]$.

Several analytical techniques based on titrimetry, spectrophotometry, and chromatography have been reported for the determination of $\mathrm{AC}, \mathrm{Caf}$ and, $\mathrm{AA}$ [12-20]. Although these methods are relatively sensitive and accurate, they are typically time-consuming, relatively expensive, and require complex preparation steps. These disadvantage of the methods limit their applications for the determination of analytes [21,22].

The electrochemical methods, due to their costeffectiveness, good sensitivity, selectivity and, rapid response have been used for the determination of many compounds [23-31]. Since some of the electroactive species have the same oxidation potential and also because of the pronounced electrode fouling, simultaneous determination of some analytes at the surface of unmodified electrodes such as carbon paste electrode (CPE), glassy carbon electrode (GCE) and screen-printed electrode (SPE) is difficult, so new electrochemical sensors have been developed for simultaneous determination of the analytes which are modified by different materials; also the results showed that the selectivity, sensitivity and, reproducibility was improved [32-34].

One of the best strategies to improve the electrochemical sensor performance is employing nanomaterials for the procurement of the sensing layer. Nanocomposites, in addition to the properties of the individual components, also show new features due to the synergetic effect. Especially, metal-oxide nanoparticles are reported to provide some unique functions, such as electrocatalytic activity and improvement of conductivity [35-39].

In recent year, some nanomaterials were used for designing of a modified electrochemical sensor to determination of AC, Caf or, AA. For example, Quang Khieu et al. used cobalt ferrite $\left(\mathrm{CoFe}_{2} \mathrm{O}_{4}\right)$ nanoparticles for modification of GCE and determined the AC, Caf or AA simultaneously in the range of 0.2-4.4 $\mu \mathrm{M}$ [40]. Murugan et al. used $\mathrm{SnS} /$ TiO2@GO composite coated GCE for measurements of AC and Caf 0.0098-280 and 0.0166-333 $\mu \mathrm{M}$, respectively [41]. Qiao et al. used Graphene (Gr) supported Pt electrochemical sensor for the determination of Caf in Tea samples [42]. In other research, Mulyasuryani et al. applied Cassava Starch-Fe $\mathrm{O}_{4}$ Nanoparticles to modify the GCE surface, for the detection of $\mathrm{AC}$ and $\mathrm{Caf}$ by voltammetric methods in headache medicines [43].

Among new nanocomposites, ternary semiconductor oxides have received more attention as a result of their optical and electronic properties. In this regard, $\mathrm{SnO}_{2}$ and $\mathrm{ZnO}$ are two oxide semiconductors with wide bandgap which have attracted attention in electrochemical sensors [44-46]. Thus, in this work $\mathrm{ZnO}$ $\mathrm{Zn}_{2} \mathrm{SnO}_{4}-\mathrm{SnO}_{2}$ with better electrical properties in comparison to $\mathrm{ZnO}$ or $\mathrm{SnO} 2$ nanoparticles was synthesized and applied for modification of the working electrode [47].

On the other hand, other nanomaterials used in electrochemical sensors are carbon-based nanomaterials such as Graphene (Gr). Gr, a multitalented twodimensional allotrope of carbon, is a 2D monolayer of carbon atoms that are bonded altogether in a honeycomb crystal lattice. Gr offers peculiar features like flexibility, excellent electrical conductivity [33], very high surface area $\left(2630 \mathrm{~m}^{2} / \mathrm{g}\right)$, which makes it a desirable candidate for designing of electrical devices 
and specially electrochemical sensors [48-50].

In the present research, we use $\mathrm{ZnO}-\mathrm{Zn}_{2} \mathrm{SnO}_{4}$ $\mathrm{SnO}_{2}$ nanocomposite and $\mathrm{Gr}$ with excellent electrocatalytic activity as a sensing layer to construct an electrochemical sensor for the simultaneous measurement of AC, Caf and, AA. The differential pulse voltammetry (DPV), cyclic voltammetry (CV) techniques were used to optimize the determination factors. Interferences study shows that the proposed method has high selectivity for the monitoring of the target analytes. Also, the constructed electrode illustrated high sensitivity, stability, and electrocatalytic activity for the oxidation of AC, Caf and, AA. The $\mathrm{ZnO}-\mathrm{Zn}_{2} \mathrm{SnO}_{4}$ $\mathrm{SnO}_{2} / \mathrm{Gr} / \mathrm{CPE}$ was efficaciously used to monitoring $\mathrm{AC}, \mathrm{Caf}$ and $\mathrm{AA}$ in different real samples.

\section{Experimental}

\subsection{Chemicals and apparatus}

All reagents and materials in this research were of analytical grade and were used without any further purification. The raw materials for the synthesis of $\mathrm{ZnO}-\mathrm{Zn}_{2} \mathrm{SnO}_{4}-\mathrm{SnO}_{2}$ composite, include zinc chloride $\left(\mathrm{ZnCl}_{2}\right)$ and tin(II) chloride $\left(\mathrm{SnCl}_{2}\right)$, glyoxylic acid monohydrate $\left(\mathrm{C}_{2} \mathrm{H}_{2} \mathrm{O}_{3} \cdot \mathrm{H}_{2} \mathrm{O}\right)$, Ammonium hydroxide $\left(\mathrm{NH}_{4} \mathrm{OH}\right)$, ethanol, the target analytes (AC, Caf and, AA), and Gr were all bought from Merck Company and applied without further refinement. Aqueous solutions were prepared with deionized water. Britton-Robinson universal buffer solution (B-R buffer solution) was prepared by mixing $0.04 \mathrm{M}$ boric acid, $0.04 \mathrm{M}$ acetic acid and $0.04 \mathrm{M}$ phosphoric acid, and used as supporting electrolytes and $\mathrm{pH}$ adjustment agent. Laboratory glasswares were kept overnight in the $10 \% \mathrm{v} / \mathrm{v} \mathrm{HNO}_{3}$ solution and before using were washed with deionized water.

All electrochemical experiments were done in the ambient temperature using an Autolab electrochemical system (302 N, Utrecht, Netherlands) with a conventional three-electrode system consisting of an $\mathrm{Ag}$ / $\mathrm{AgCl} / \mathrm{KCl}$ (3 M) electrode as a reference electrode, modified and unmodified CPE as the working electrode and a Pt wire as the counter electrode. The $\mathrm{pH}$ of solutions was measured by a Metrohm $\mathrm{pH}$ meter (model 713-Switzerland). SEM images were taken using SEM-EDX, XL30, Philips Netherland. FTIR spectra were obtained by a Perkin-Elmer spectrophotometer (Spectrum GX), and XRD patterns were determined by a 38066 Riva, d/G.Via M. Misone, 11/
D (TN) Italy at ambient temperature.

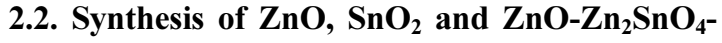 $\mathrm{SnO}_{2}$ nanocomposite as modifiers}

$\mathrm{ZnO}-\mathrm{Zn}_{2} \mathrm{SnO}_{4}-\mathrm{SnO}_{2}$ nanocomposite synthesis: In the first step, a mixture of $0.1 \mathrm{M} \mathrm{ZnCl}_{2}(0.409 \mathrm{~g})$ and $0.1 \mathrm{M} \mathrm{SnCl}_{2}\left(0.569 \mathrm{~g}\right.$ ) with $\mathrm{C}_{2} \mathrm{H}_{2} \mathrm{O}_{3} . \mathrm{H}_{2} \mathrm{O}$ (Glyoxylic acid monohydrate) were prepared in $30 \mathrm{~mL}$ deionized water and stirred for $30 \mathrm{~min}$, then $\mathrm{NH}_{4} \mathrm{OH}$ was added dropwise to the solution and kept under stirring at ambient temperature until $\mathrm{pH}$ adjusted to 9 at ambient temperature. The obtained gel was transferred to a 50-mL Teflon lined stainless steel autoclave and kept at $170^{\circ} \mathrm{C}$ for $3 \mathrm{~h}$. In the next step, the prepared aerogel was accumulated and washed with deionized water and absolute ethanol three times and then air-dried. Finally, it was calcined at $650^{\circ} \mathrm{C}$ for 3 h. $\mathrm{ZnO}, \mathrm{SnO}_{2}$ nanoparticle synthesis: For the synthesis of $\mathrm{ZnO}$ and $\mathrm{SnO}_{2}$ nanoparticles, the same procedures were applied without the addition of $\mathrm{SnCl}_{2}$ and $\mathrm{ZnCl}_{2}$, respectively [47].

\subsection{Preparation of modified CPEs}

For fabrication of CPEs, briefly, the graphite powder and paraffin oil (75:25 w/w \%) were mixed in a mortar using a pestle. To prepare Gr/CPE, 15\% w/w of the Gr were well mixed with the graphite powder. The mixture was blended with paraffin oil to obtain a homogeneous paste where the percentage of components in the modified paste was 15:60:25 w/w\% for the modifier, graphite powder, and paraffin, respectively. The $\mathrm{SnO}_{2} / \mathrm{Gr} / \mathrm{CPE}, \mathrm{ZnO} / \mathrm{Gr} / \mathrm{CPE}$ and, $\mathrm{ZnO}-$ $\mathrm{Zn}_{2} \mathrm{SnO}_{4}-\mathrm{SnO}_{2} / \mathrm{Gr} / \mathrm{CPE}$ were constructed in the same way by $10 \% \mathrm{SnO}_{2}, \mathrm{ZnO}$ or $\mathrm{ZnO}-\mathrm{Zn}_{2} \mathrm{SnO}_{4}-\mathrm{SnO}_{2}, 5 \%$ Gr, $60 \%$ graphite powder and $25 \%$ paraffin oil.

Finally, for the fabrication of modified CPEs, each prepared paste was carefully packed into the pistondriven carbon paste electrode holder in such a way that all air bubbles between layers come out. The new surface of modified or bare CPE was mechanically renewed by scraping out the old surface with a soft paper.

\subsection{Spiked and Real samples preparation}

The applicability of the $\mathrm{ZnO}-\mathrm{Zn}_{2} \mathrm{SnO}_{4}-\mathrm{SnO}_{2} / \mathrm{Gr} /$ $\mathrm{CPE}$ for determination of $\mathrm{AC}, \mathrm{Caf}$ and, $\mathrm{AA}$ in different real samples was examined using the standard addition technique.

For the preparation of a urine sample, a $20 \mathrm{~mL}$ of 
the collected sample was centrifuged for $40 \mathrm{~min}$ at $2000 \mathrm{rpm}$; then, the supernatant was filtered using a $0.45 \mathrm{~mm}$ filter. The obtained sample was diluted 5times with the supporting electrolyte of $\mathrm{pH}$ 7.2. The prepared urine sample was stored in a refrigerator before using [51].

In order to remove redundant proteins in the plasma samples, $1.0 \mathrm{~mL}$ of the blood samples was mixed with $150 \mu \mathrm{L}$ perchloric acid and stirred for 1 $\min$. In the next step, the mixture was centrifuged at $2000 \mathrm{rpm}$ for $40 \mathrm{~min}$. The obtained supernatant was added to a $10 \mathrm{~mL}$ B-R buffer solution of $\mathrm{pH}=7.2$ and transferred to the electrochemical cell without any further pretreatment [52].

\section{Results and Discussion}

3.1. Surface characterization of the differently prepared nanocomposites

The crystalline structure of $\mathrm{SnO}_{2}, \mathrm{ZnO}$ and, $\mathrm{ZnO}$ $\mathrm{Zn}_{2} \mathrm{SnO}_{4}-\mathrm{SnO}_{2}$ nanocomposite was characterized by using XRD, and the results are depicted in Fig. 1a. The XRD pattern of $\mathrm{SnO}_{2}$ nanoparticles shows the main characteristic peaks (110), (101), and (211) at $2 \theta=26.16^{\circ}, 34.73^{\circ}$, and $52.34^{\circ}$, respectively. The observed peaks were attributed to the formation of the monoclinic phase of $\mathrm{SnO}_{2}$ (JCPDS No. 41-1445) [53].

The XRD pattern of $\mathrm{ZnO}$ nanoparticles illustrates 10 peaks at $2 \theta=31.56^{\circ}(100), 34.16^{\circ}(002), 36.04^{\circ}(101)$, $47.47^{\circ}(102), 56.64^{\circ}(110), 62.87^{\circ}(103), 66.46^{\circ}(200)$, $67.97^{\circ}(112), 69.19^{\circ}(201)$, and $72.65^{\circ}(004)$, which are well agree with JCPDS 36-1451 [54].

The XRD pattern of $\mathrm{ZnO}-\mathrm{Zn}_{2} \mathrm{SnO}_{4}-\mathrm{SnO}_{2}$ nanocomposite represents distinct peaks at $2 \theta=26.36^{\circ}$, $37.69^{\circ}, 41.46^{\circ}, 51.54^{\circ}, 56.48^{\circ}, 60.27^{\circ}$, and $62.76^{\circ}$ (these peaks are related to $\mathrm{SnO}_{2}$ ), $31.52^{\circ}, 36.08^{\circ}$, $56.48^{\circ}, 65.99^{\circ}, 67.73^{\circ}, 69.02^{\circ}$ and $72.28^{\circ}$ (these peaks are related to $\mathrm{ZnO}$ ) and $17.46^{\circ}, 28.99^{\circ}, 34.18^{\circ}$, $47.45^{\circ}, 51.54^{\circ}$ and $62.76^{\circ}$ (these peaks are related to $\mathrm{Zn}_{2} \mathrm{SnO}_{4}$, which well agrees with JCPDS 24-1470), which are well-matched with tetragonal structured $\mathrm{SnO} 2$ nanoparticles and the hexagonal wurtzite structured $\mathrm{ZnO}$ nanoparticles [55].

The FTIR technique was used for investigation of the functional group of the synthesized $\mathrm{SnO}_{2}, \mathrm{ZnO}$ and, $\mathrm{ZnO}-\mathrm{Zn}_{2} \mathrm{SnO}_{4}-\mathrm{SnO}_{2}$ nanocomposite, and the FTIR spectra are shown in Fig. $1 \mathrm{~b}$.

The FTIR spectrum of $\mathrm{SnO}_{2}$ shows several bands at $3417,2979,1626 \mathrm{~cm}^{-1}$ (vibration of hydroxyl group), 787, 906 and $958 \mathrm{~cm}^{-1}$ (vibration of $\mathrm{Sn}=\mathrm{O}$

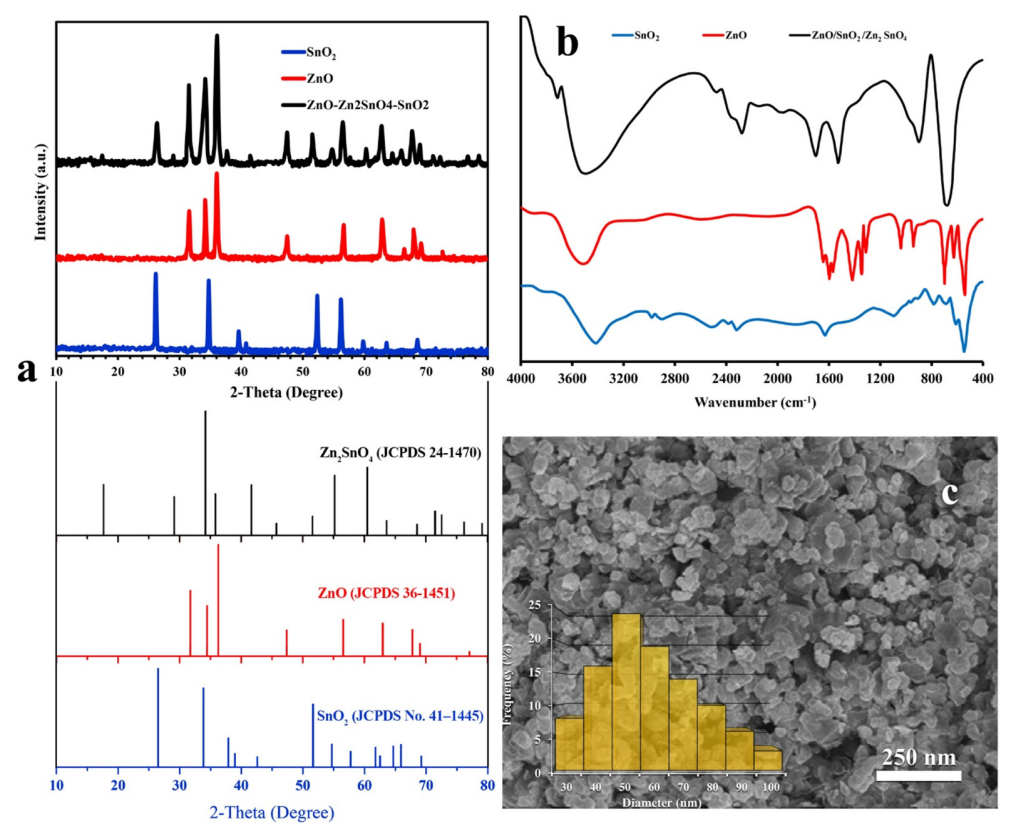

Fig. 1. (a) The XRD patterns, the XRD standard pattern (b) the FTIR spectra of the synthesized $\mathrm{SnO}_{2}, \mathrm{ZnO}$ and $\mathrm{ZnO}$ $\mathrm{Zn}_{2} \mathrm{SnO}_{4}-\mathrm{SnO}_{2}$; (c) SEM image of $\mathrm{ZnO}-\mathrm{Zn}_{2} \mathrm{SnO}_{4}-\mathrm{SnO}_{2}$ (Inset: The plot of particle size). 
and $\mathrm{Sn}-\mathrm{O}), 546 \mathrm{~cm}^{-1}$ (Sn-O antisymmetric vibrations), $685 \mathrm{~cm}^{-1}$ (Sn-O-Sn vibrations) [56]. For the $\mathrm{ZnO}$ nanoparticles sample, the FTIR spectrum represents the peaks at $3507 \mathrm{~cm}^{-1}$ (O-H stretching), $1643 \mathrm{~cm}^{-1}$ (Zn-O stretching), $627 \mathrm{~cm}^{-1}$ (Zn-O deformation vibration) and $539 \mathrm{~cm}^{-1}$ is attributed to $\mathrm{Zn}-\mathrm{O}$ [57]. For $\mathrm{ZnO}-\mathrm{Zn}_{2} \mathrm{SnO}_{4}-\mathrm{SnO}_{2}$ nanocomposite, the FTIR spectrum shows two strong absorbance band at 3515 and $1529 \mathrm{~cm}^{-1}$ which are attributed to the stretching vibration of $\mathrm{H}-\mathrm{O}-\mathrm{H}$ and bending vibrations of $\mathrm{O}-\mathrm{H}$, respectively. Also, the peaks around 673,896 , and $1701 \mathrm{~cm}^{-1}$ correspond to the vibration of metal-oxygen or metal-oxygen-metal in $\mathrm{SnO}_{2}, \mathrm{Zn}_{2} \mathrm{SnO}_{4}$ and $\mathrm{ZnO}$ [58]. An intense and broad band in the range of 3500 to $3200 \mathrm{~cm}^{-1}$ in the synthesized $\mathrm{SnO}_{2}, \mathrm{ZnO}$ nanoparticles and $\mathrm{ZnO}-\mathrm{Zn}_{2} \mathrm{SnO}_{4}-\mathrm{SnO}_{2}$ nanocomposite is assigned to $\mathrm{O}-\mathrm{H}$ stretching of water molecule absorbed on the surface of nanomaterials [59-61].

In order to investigate the size, morphology and, uniformity of synthesized the nanocomposites, SEM analysis was conducted. The SEM image in Fig. 1c shows the morphology of the prepared $\mathrm{ZnO}$ $\mathrm{Zn}_{2} \mathrm{SnO}_{4}-\mathrm{SnO}_{2}$ nanocomposite with an average size of approximately $50 \mathrm{~nm}$, and the inset shows the range of nanocomposite size.

The provided results by FTIR, XRD and, SEM analysis confirmed the successful formation of the $\mathrm{ZnO}-\mathrm{Zn}_{2} \mathrm{SnO}_{4}-\mathrm{SnO}_{2}$ nanocomposite.

\subsection{Investigation electrochemical reactivity of the constructed electrodes}

The electrochemical characteristic of the con- structed modified and unmodified sensor was investigated in the presence of $5.0 \mathrm{mM}\left[\mathrm{Fe}(\mathrm{CN})_{6}\right]^{3-/ 4-}$ and $1.0 \mathrm{M} \mathrm{KCl}$ by the cyclic voltammetry technique (CV).

The voltammograms of CPE, Gr/CPE, $\mathrm{SnO}_{2} / \mathrm{Gr} /$ $\mathrm{CPE}, \mathrm{ZnO} / \mathrm{Gr} / \mathrm{CPE}$ and, $\mathrm{ZnO}-\mathrm{Zn}_{2} \mathrm{SnO}_{4}-\mathrm{SnO}_{2} / \mathrm{Gr} /$ $\mathrm{CPE}$ are shown in Fig. 2a. The probe illustrates a weak redox peak with high electrochemical peak separation $(\triangle E p)$ by using the bare $\mathrm{CPE}$ as the working electrode. By modification of CPE with Gr, the electrochemical responses have increased, and the $\Delta \mathrm{Ep}=$ Epa - Epc has reduced to $304 \mathrm{mV}$. Besides, welldefined cathodic and anodic peaks were observed at the $\mathrm{SnO}_{2} / \mathrm{Gr} / \mathrm{CPE}$ and $\mathrm{ZnO} / \mathrm{Gr} / \mathrm{CPE}$, with $\triangle E p=234$ and $184 \mathrm{mV}$, respectively. Also, for these two electrodes, the electrochemical currents were 1.74 and 2.26-fold in comparison to $\mathrm{Gr} / \mathrm{CPE}$.

Furthermore, by the addition of $\mathrm{ZnO}-\mathrm{Zn}_{2} \mathrm{SnO}_{4}$ $\mathrm{SnO}_{2}$ and $\mathrm{Gr}$ into the matrix of paste, the redox currents increase significantly while the $\triangle E p$ is reduced to $170 \mathrm{mV}$. The redox current is about $2.61,1.5$ and 1.15 time than those of $\mathrm{Gr} / \mathrm{CPE}, \mathrm{SnO}_{2} / \mathrm{Gr} / \mathrm{CPE}$, and $\mathrm{ZnO} / \mathrm{Gr} / \mathrm{CPE}$, and the $\triangle E p$ was minimum among all other investigated electrodes (about $0.5,0.73$ and 0.92 -old compared with $\mathrm{Gr} / \mathrm{CPE}, \mathrm{SnO}_{2} / \mathrm{Gr} / \mathrm{CPE}$, and $\mathrm{ZnO} / \mathrm{Gr} / \mathrm{CPE}$, respectively).

A hybrid nanomaterial comprised of $\mathrm{ZnO}$ and $\mathrm{SnO}_{2}$ nanoparticles like $\mathrm{ZnO}-\mathrm{Zn}_{2} \mathrm{SnO}_{4}-\mathrm{SnO}_{2}$ nanocomposite act as a multi-component system in which two or more of its combinations result in the enhancement of functional properties. Both $\mathrm{ZnO}$ and $\mathrm{SnO}_{2}$ are well-known wide direct band-gap $(\mathrm{Eg}=$
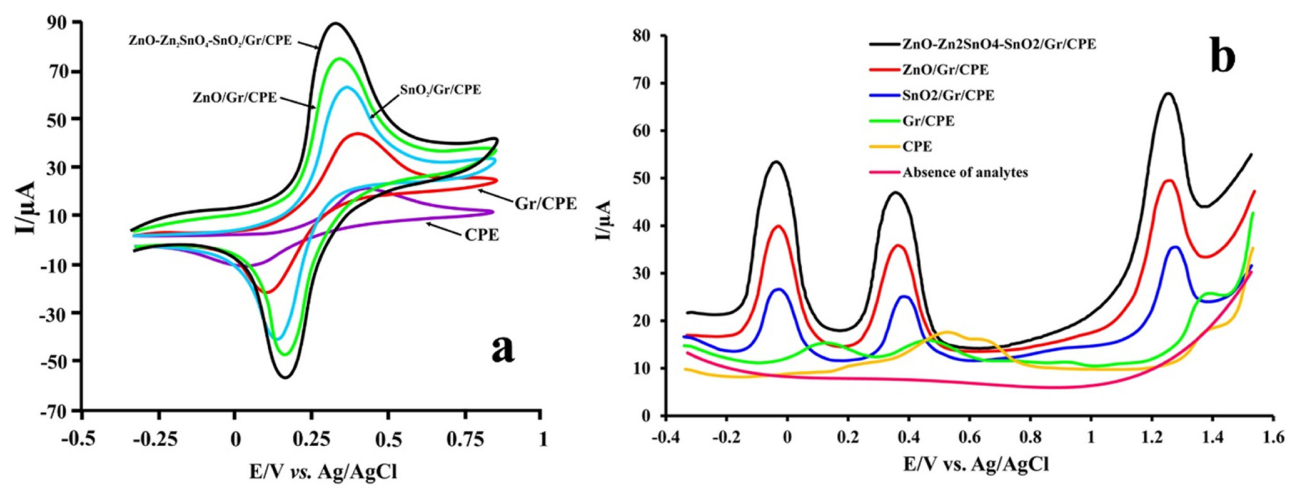

Fig. 2. (a) $\mathrm{CVs}$ of the bare $\mathrm{CPE}, \mathrm{Gr} / \mathrm{CPE}, \mathrm{SnO}_{2} / \mathrm{Gr} / \mathrm{CPE}, \mathrm{ZnO} / \mathrm{Gr} / \mathrm{CPE}$ and $\mathrm{ZnO}-\mathrm{Zn}_{2} \mathrm{SnO}_{4}-\mathrm{SnO}{ }_{2} / \mathrm{Gr} / \mathrm{CPE}$ in $5.0 \mathrm{mM}$ $\left[\mathrm{Fe}(\mathrm{CN})_{6}\right]^{3-/ 4-}$ and $1.0 \mathrm{M} \mathrm{KCl}$ (Scan Rate $=100 \mathrm{mV} / \mathrm{s}$ ); (b) DPV of the bare CPE, $\mathrm{Gr} / \mathrm{CPE}, \mathrm{SnO}_{2} / \mathrm{Gr} / \mathrm{CPE}, \mathrm{ZnO} / \mathrm{Gr} / \mathrm{CPE}$ and $\mathrm{ZnO}-\mathrm{Zn}_{2} \mathrm{SnO}_{4}-\mathrm{SnO}_{2} / \mathrm{Gr} / \mathrm{CPE}$ in the presence of $7.0 \mu \mathrm{M}$ AA, $5.0 \mu \mathrm{M} \mathrm{AC}$ and $6.0 \mu \mathrm{M} \mathrm{Caf}$ and $\mathrm{ZnO}-\mathrm{Zn}_{2} \mathrm{SnO}_{4}-\mathrm{SnO}_{2} / \mathrm{Gr} / \mathrm{CPE}$ in the absence of the analytes. 
$3.37 \mathrm{eV}$ and $3.6 \mathrm{eV}$ at $300 \mathrm{~K}$ respectively) semiconductors, and both serve as an excellent candidate in the field of electrochemistry and physics, especially using in the electrochemical sensor as a modifier with electrocatalytic properties. Recent investigations also state that the addition of a secondary component oxide in the form of the composite inhibits the grain growth of the host material and these coupled oxides with different bandgap widths are the effective approaches to enhance the electrocatalytic effect in comparison to $\mathrm{ZnO}$ and $\mathrm{SnO}_{2}$ nanoparticles [62-64].

\subsection{DPV behavior of the modified electrodes}

The electrochemical behavior of $7 \mu \mathrm{M} \mathrm{AA}, 5 \mu \mathrm{M}$ $\mathrm{AC}$, and $6 \mu \mathrm{M}$ Caf at $\mathrm{pH}=7.2$ on the $\mathrm{CPE}, \mathrm{Gr} / \mathrm{CPE}$, $\mathrm{SnO} / \mathrm{Gr} / \mathrm{CPE}, \mathrm{ZnO} / \mathrm{Gr} / \mathrm{CPE}$ and, $\mathrm{ZnO}-\mathrm{Zn} 2 \mathrm{SnO} 4-$ $\mathrm{SnO} / \mathrm{Gr} / \mathrm{CPE}$ was studied by DPV, and the obtained voltammograms are shown in Fig. $2 b$.

As can be seen in this figure, the bare CPE shows two broad and weak peaks at 0.524 and $1.4 \mathrm{~V}$ and a shoulder at $0.623 \mathrm{mV}$ related to $\mathrm{AA}, \mathrm{Caf}$ and, $\mathrm{AC}$, respectively. It should be noted that, since the oxidation peak potential $(E p a)$ separation for $\mathrm{AA}$ and $\mathrm{AC}$ on the surface of bare CPE is not large enough ( $\triangle E p a$ $(\mathrm{AA}-\mathrm{AC})=99 \mathrm{mV})$, the simultaneous determination of the analytes by using this electrode was not possible. Modification of CPE with Gr leads to the separation of oxidation peaks of AA and AC ( $\triangle E p a$ (AA$\mathrm{AC})=332 \mathrm{mV}$ ) while the oxidation currents (Ipa) of $\mathrm{AA}$ and $\mathrm{AC}$ remain about $5 \mu \mathrm{A}$. However, the oxidation current for $\mathrm{Caf}$ has been relatively increased. Compared to the $\mathrm{Gr} / \mathrm{CPE}$, at the surface of $\mathrm{SnO}_{2} / \mathrm{Gr} /$ $\mathrm{CPE}$ and $\mathrm{ZnO} / \mathrm{Gr} / \mathrm{CPE}$ three well-defined peaks with the shifts of about $-23,398$ and, $-1280 \mathrm{mV}$ for AA, $\mathrm{AC}$ and $\mathrm{Caf}$, respectively. Base on the results $\triangle E p a$ $(\mathrm{AA}-\mathrm{AC})=421 \mathrm{mV}$ and $\triangle E p a(\mathrm{AC}-\mathrm{Caf})=0.882$ $\mathrm{mV}$, so the simultaneous measurement of the mention molecules became possible. Besides, the $\mathrm{SnO}_{2} / \mathrm{Gr} /$ $\mathrm{CPE}$ and $\mathrm{ZnO} / \mathrm{Gr} / \mathrm{CPE}$ improved the oxidation peaks current of AA and AC, Caf significantly.

The best voltammograms were recorded at $\mathrm{ZnO}$ $\mathrm{Zn}_{2} \mathrm{SnO}_{4}-\mathrm{SnO}_{2} / \mathrm{Gr} / \mathrm{CPE}$. The Ipa for AA and AC, Caf at this electrode were increased by almost 6.77, 7.60 and, 4.81-fold compared to Gr/CPE, which is due to the synergetic effect of $\mathrm{ZnO}-\mathrm{Zn}_{2} \mathrm{SnO}_{4}-\mathrm{SnO}_{2}$ nanocomposite and $\mathrm{Gr}$ as electrocatalytic modifiers and the larger surface area of the nanocomposite film. In the absence of target analytes ions, the $\mathrm{ZnO}$ $\mathrm{Zn}_{2} \mathrm{SnO}_{4}-\mathrm{SnO}_{2} / \mathrm{Gr} / \mathrm{CPE}$ did not show any oxidation peaks in the potential window between -0.4 and $1.5 \mathrm{~V}$.

The electrocatalytic ability of $\mathrm{ZnO}-\mathrm{Zn}_{2} \mathrm{SnO}_{4}-\mathrm{SnO}_{2} /$ $\mathrm{Gr} / \mathrm{CPE}$ which results in the increased Ipa and peak separation makes it the best choice among the other electrodes for the simultaneous determination of AA and $\mathrm{AC}, \mathrm{Caf}$; therefore it was used as working electrode in following experiments.

\subsection{The impact of solution $\mathrm{pH}$ on the oxidation of $\mathrm{AA}$ and $\mathrm{AC}$, $\mathrm{Caf}$ at the $\mathrm{ZnO}-\mathrm{Zn}_{2} \mathrm{SnO}_{4}-\mathrm{SnO}_{2} / \mathrm{Gr} /$ CPE}

The CV and DPV techniques were used for investigating the impact of $\mathrm{pH}$ value on the oxidation peak potentials and peak currents of the $3 \mu \mathrm{M}$ analytes at the $\mathrm{ZnO}-\mathrm{Zn}_{2} \mathrm{SnO}_{4}-\mathrm{SnO}_{2} / \mathrm{Gr} / \mathrm{CPE}$ in a $\mathrm{pH}$ range of 510 (Fig. 3a and 3d-f). It is clear from DPVs that by increasing the value the peak currents of AA, AC, and Caf have been initially increased and have reached the maximum value at $\mathrm{pH}=7.2$, then they show a downtrend with increasing the $\mathrm{pH}$ values between 7.5 and 10 (Fig. 3b).

Besides it can be seen that by increasing the $\mathrm{pH}$ values, the oxidation peak potentials of the target molecules have shifted to the negative direction and the relationship between peak potential (Fig. 3c) and $\mathrm{pH}$ is linear as following equations:
AA $E p a=-0.0516 \mathrm{pH}+0.3478$
$\mathrm{R}^{2}=0.9904$
AC $E p a=-0.0617 \mathrm{pH}+0.7905$
$\mathrm{R}^{2}=0.9952$
Caf $E p a=-0.0504 \mathrm{pH}+1.6068$
$\mathrm{R}^{2}=0.9917$

The obtained slope values $(d E p a / d p H)$ for AA, $\mathrm{AC}$, and Caf were very close to the theoretical value of $59 \mathrm{mV} / \mathrm{pH}$ at $25^{\circ} \mathrm{C}$ expected from the Nernst equation, which indicates that same number of protons and electrons have participated in the electro-oxidation of the analytes at the surface of $\mathrm{ZnO}-\mathrm{Zn}_{2} \mathrm{SnO}_{4}$ $\mathrm{SnO}_{2} / \mathrm{Gr} / \mathrm{CPE}$. Based on these results and also concerning the previous studies, it was proposed that for the oxidation of AA and AC two electrons an two protons are involved, while for the oxidation of Caf four electrons and four protons are participating (see Scheme 1) [10,65].

Further studies on the impact of $\mathrm{pH}$ on the electrooxidation of $3 \mu \mathrm{M}$ analytes at the $\mathrm{ZnO}-\mathrm{Zn}_{2} \mathrm{SnO}_{4}{ }^{-}$ $\mathrm{SnO}_{2} / \mathrm{Gr} / \mathrm{CPE}$ carried out using $\mathrm{CV}$ technique, and the obtained voltammograms are depicted in Fig. 3d- 

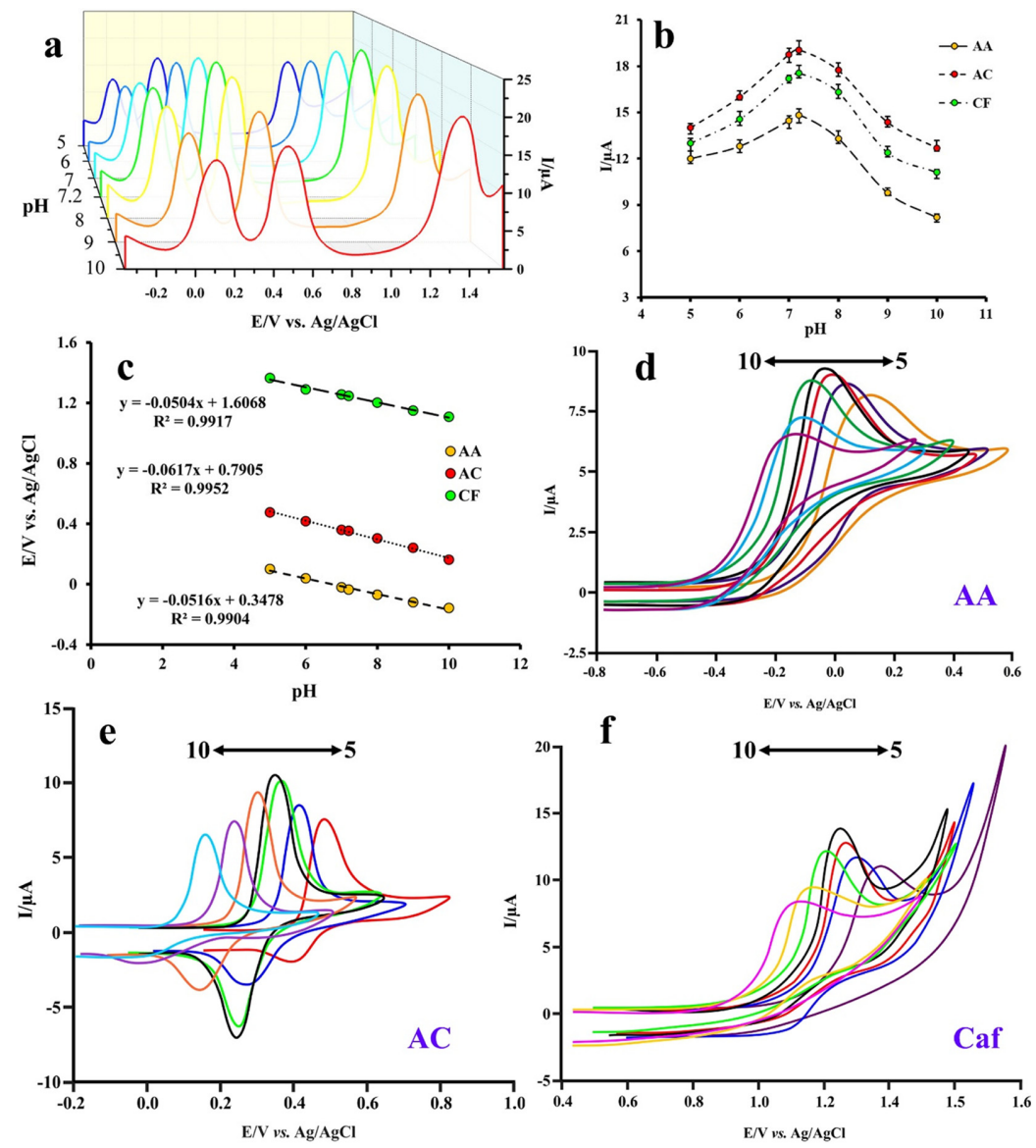

Fig. 3. (a) The DPV of $3 \mu \mathrm{M} \mathrm{AA}, \mathrm{AC}$ and $\mathrm{Caf}$ at $\mathrm{ZnO}-\mathrm{Zn}_{2} \mathrm{SnO}_{4}-\mathrm{SnO}_{2} / \mathrm{Gr} / \mathrm{CPE}$ at different $\mathrm{pH}$ include 5,6,7,7.2,8,9, and 10; The influence of $\mathrm{pH}$ on (b) current and (c) potential of the peak of the analytes; The CV of $3 \mu \mathrm{M}$ (d) AA, (e) AC and (f) $\mathrm{Caf}$ at $\mathrm{ZnO}-\mathrm{Zn}_{2} \mathrm{SnO}_{4}-\mathrm{SnO}_{2} / \mathrm{Gr} / \mathrm{CPE}$ at different $\mathrm{pH}$ between 5 and 10 . The number of replicates $(\mathrm{n})=5$.<smiles>CC#CCCCC(C)C1OC(=O)C(=O)C1=O</smiles><smiles></smiles>

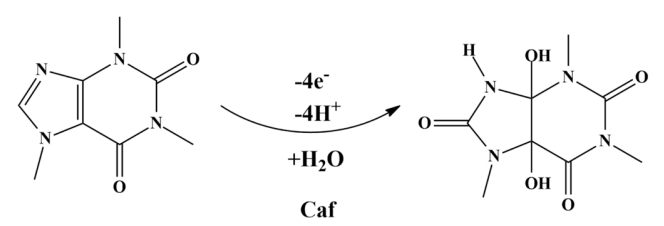

Scheme 1. Electrochemical suggested oxidation mechanism for $\mathrm{AA}, \mathrm{AC}$ and $\mathrm{Caf}$. f. AA and Caf show an irreversible peak with the maximum current at $\mathrm{pH}=7.2$. Also, the peak potential was affected by changes in $\mathrm{pH}$ and have shifted negatively by increasing $\mathrm{pH}$ value.

\subsection{Effect of scan rate on $\mathrm{AA}$ and $\mathrm{AC}$, Caf oxida- tion at $\mathrm{ZnO}-\mathrm{Zn}_{2} \mathrm{SnO}_{4}-\mathrm{SnO}_{2} / \mathrm{Gr} / \mathrm{CPE}$}

$\mathrm{CV}$ s obtained for $5 \mu \mathrm{M}$ AA and $\mathrm{AC}$, Caf at $\mathrm{ZnO}-$ $\mathrm{Zn}_{2} \mathrm{SnO}_{4}-\mathrm{SnO}_{2} / \mathrm{Gr} / \mathrm{CPE}$ in $0.1 \mathrm{M}$ B-R buffer solution $\mathrm{pH}=7.2$ at scan rates ranging from 10 to $400 \mathrm{mV} / \mathrm{s}$ are shown in Fig. 4aI, 4bI and, cI. As can be seen, the response of the electrode for oxidation of three analytes increases while the rate of scanning the potentials increasing between 10 and $400 \mathrm{mV} / \mathrm{s}$, the relationship between the current signals and square root of scan rates is linear with the equations: AA: Ipa $=1.2321 v 1 / 2-1.2448\left(\mathrm{R}^{2}=0.9953\right), \mathrm{AC}:$ Ip $\mathrm{a}=$ 


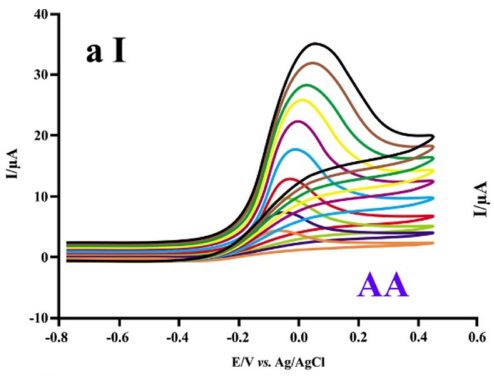

a II
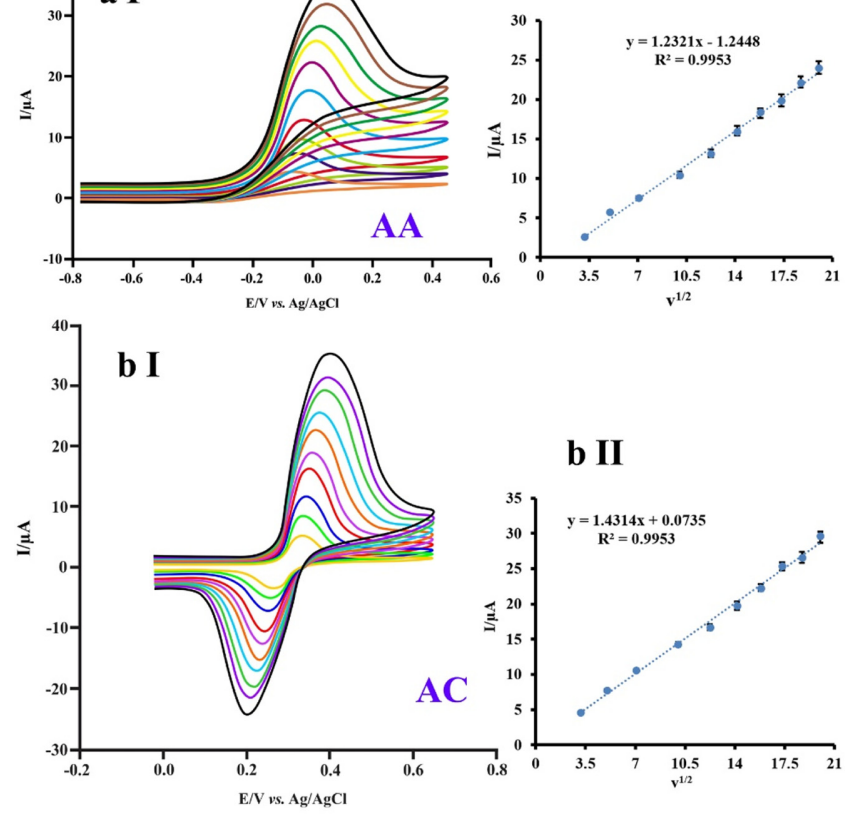

b II
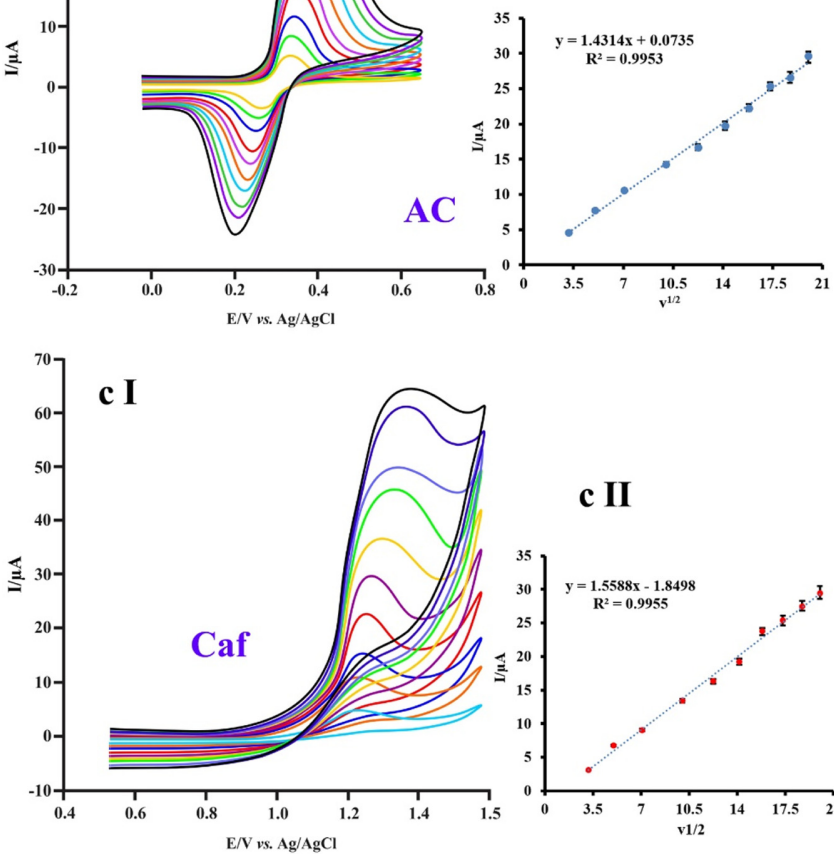

\section{c II}

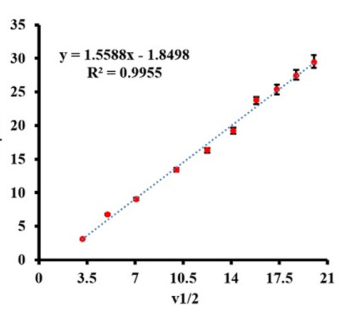

a III

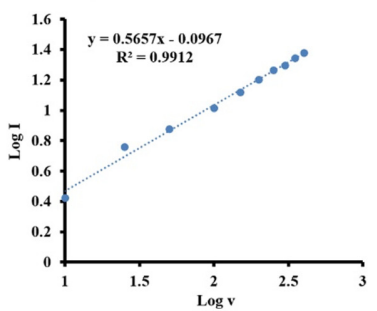

b III

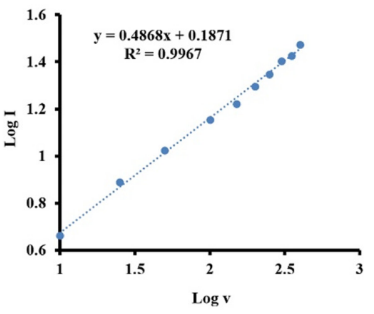

Fig. 4. $\mathrm{CVs}$ at $\mathrm{ZnO}-\mathrm{Zn}_{2} \mathrm{SnO}_{4}-\mathrm{SnO}_{2} / \mathrm{Gr} / \mathrm{CPE}$ in $\mathrm{B}-\mathrm{R}$ buffer solution with $\mathrm{pH} 7.2$ containing $5 \mu \mathrm{M}$ (aI) AA, (bI) AC and (cI) Caf with scan rates ranging from 10 to $400 \mathrm{mV} \mathrm{s}^{-1}$; The linear relationship between the peak current vs. square root of the scan rate $\left(v^{1 / 2}\right)$ for aII: AA, bII: AC and cII: Caf; The linear relationship between the Log peak current vs. Log scan rate for aIII: AA, bIII: AC and cIII: Caf, $\mathrm{n}=5$.

$1.4314 v 1 / 2+0.0735\left(\mathrm{R}^{2}=0.9953\right)$ and Caf: Ipa $=$ $1.5588 \mathrm{v} 1 / 2-1.8498\left(\mathrm{R}^{2}=0.9955\right)$, which indicates that the electrochemical oxidation reactions of AA, $\mathrm{AC}$ and $\mathrm{Caf}$ at $\mathrm{ZnO}-\mathrm{Zn}_{2} \mathrm{SnO}_{4}-\mathrm{SnO}_{2} / \mathrm{Gr} / \mathrm{CPE}$ are diffusion-controlled processes (Fig. 4aII, 4bII and, cII).

According to previous reports, when the slope of the logarithm of the oxidation peak currents versus the logarithm of scan rates is 0.5 , the electrochemical reaction is a diffusion-controlled process. In contrast, the slope of 1 , the electrochemical reaction occurs via an adsorption-controlled process [66]. Therefore, based on the obtained results, i.e., Equations. 4-6, and Fig. 4aIII, 4bIII, and cIII diffusion-controlled processes for the oxidation of $\mathrm{AA}, \mathrm{AC}$, and $\mathrm{Caf}$ on the $\mathrm{ZnO}-\mathrm{Zn}_{2} \mathrm{SnO}_{4}-\mathrm{SnO}_{2} / \mathrm{Gr} / \mathrm{CPE}$ are expected.
AA $\log I p a=0.5657 \log v-0.0967 \quad \mathrm{R}^{2}=0.9912$
AC $\log \operatorname{Ipa}=0.4868 \log v+0.1871 \quad \mathrm{R}^{2}=0.9967$
Caf $\log I p a=0.5879 \log v-0.052 \quad \mathrm{R}^{2}=0.9924$ 

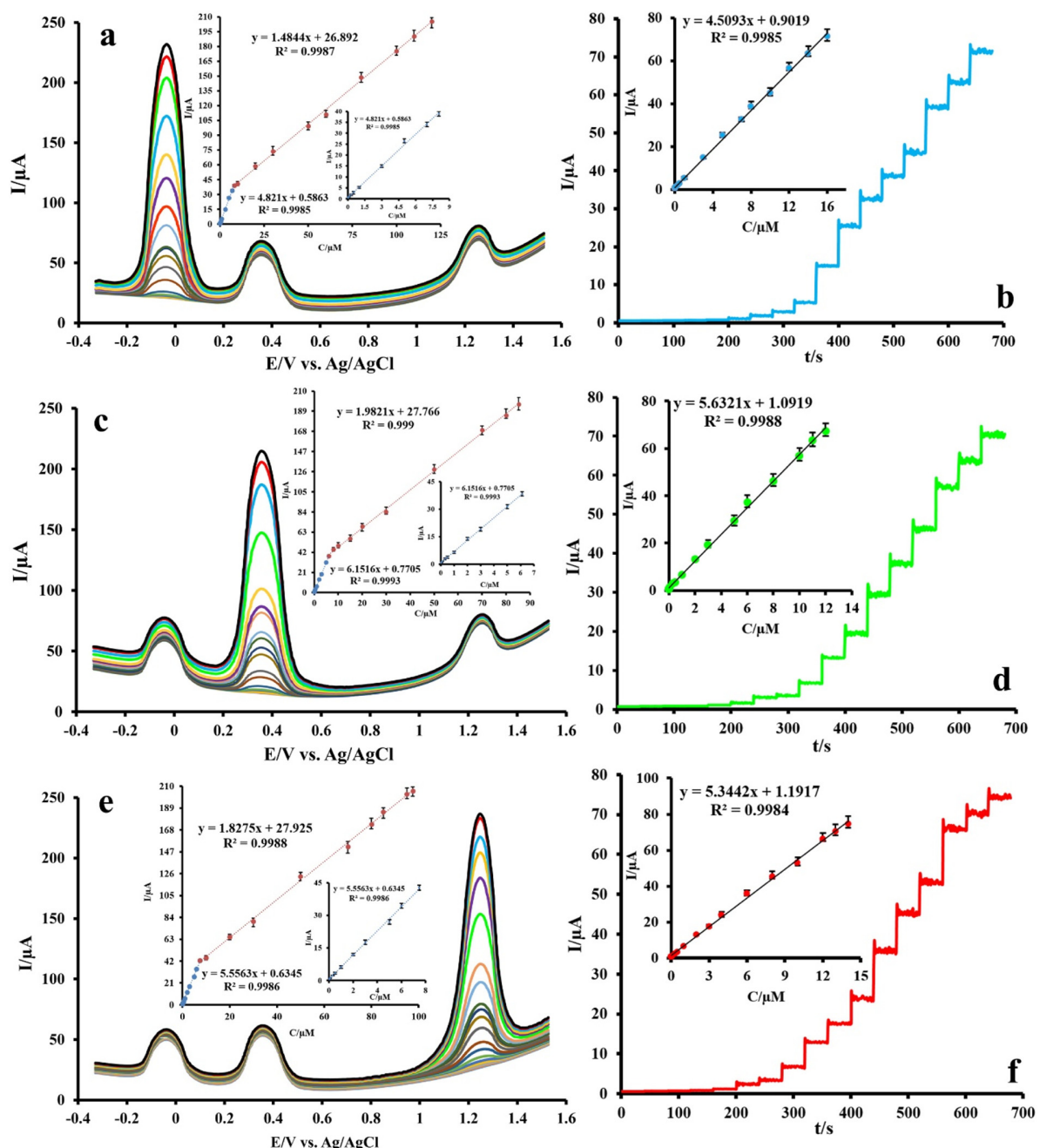

Fig. 5. DPVs at $\mathrm{ZnO}-\mathrm{Zn}_{2} \mathrm{SnO}_{4}-\mathrm{SnO}_{2} / \mathrm{Gr} / \mathrm{CPE}$ in $\mathrm{B}-\mathrm{R}$ buffer solution $\mathrm{pH}=7.2$ for (a) AA: $0.021-8.06$ and $8.06-120 \mu \mathrm{M}$ in the presence of $8.0 \mu \mathrm{M} \mathrm{AC}$ and $6.0 \mu \mathrm{M} \mathrm{Caf}$, (c) AC: $0.018-6.12$ and $6.12-85.3 \mu \mathrm{M}$ in the presence of $7.0 \mu \mathrm{M} \mathrm{AA}$ and $6.0 \mu \mathrm{M}$ Caf, (e) Caf: $0.02-7.46$ and 7.46-97.51 $\mu \mathrm{M}$ in the presence of $8.0 \mu \mathrm{M} \mathrm{AC}$ and 7.0 $\mu \mathrm{M} \mathrm{AA}, \mathrm{n}=5$. Amperometric responses of the $\mathrm{ZnO}-\mathrm{Zn}_{2} \mathrm{SnO}_{4}-\mathrm{SnO}_{2} / \mathrm{Gr} / \mathrm{CPE}$ for determination of (b) AA, (d) $\mathrm{AC}$ and (f) Caf in the applied potential of $-0.023,0.398$ and $1.28 \mathrm{~V}$ for $\mathrm{AA}, \mathrm{AC}$ and $\mathrm{Caf}$, respectively; in $\mathrm{B}-\mathrm{R}$ buffer solution $\mathrm{pH}=7.2$ and the constant stirring rate of $100 \mathrm{rpm}$.

\subsection{Calibration curve and analytical parameters for AA, AC and Caf determination}

Method validation such as linear range of determination, correlation coefficients of the calibration curve, and detection limits (DLs) were investigated using DPV and amperometric techniques at $\mathrm{pH}=7.2$ (Fig. 5).

As can be seen in Fig. 5 a, c and e, under the optimized conditions, the voltammetric anodic peak currents of each analyte in the presence of a fixed amount of the two other analytes were proportional to the concentration with the regression equation in the linear range of AA: 0.021-8.06 (Ipa $=4.821 \mathrm{C}+$ $\left.0.5863 ; \mathrm{R}^{2}=0.9985\right)$ and $8.06-120 \mu \mathrm{M}($ Ipa $=$ $\left.1.4844 \mathrm{C}+26.892: \mathrm{R}^{2}=0.9987\right), \mathrm{AC}: 0.018-6.12$ $\left(I p a=6.1516 \mathrm{C}+0.7705 ; \mathrm{R}^{2}=0.9993\right)$ and 6.12$85.3 \mu \mathrm{M}\left(I p a=1.9821 \mathrm{C}+27.766 ; \mathrm{R}^{2}=0.999\right)$, Caf: $0.02-7.46\left(\right.$ Ipa $\left.=5.5563 \mathrm{C}+0.6345 ; \mathrm{R}^{2}=0.9986\right)$ and 7.46-97.51 $\mu \mathrm{M}\left(\right.$ Ipa $=1.8275 \mathrm{C}+27.925 ; \mathrm{R}^{2}=$ 0.9988).

Also, the amperometric technique was used for the monitoring of the analytes by stirring the B-R buffer 
solution with $\mathrm{pH}=7.2$ at a constant rate of $100 \mathrm{rpm}$, and the obtained currents were collected at a fixed potential of $-0.023,0.398$ and $1.28 \mathrm{~V}$ for $\mathrm{AA}, \mathrm{AC}$ and Caf, respectively.

Fig. $5 \mathrm{~b}, \mathrm{~d}$ and $\mathrm{f}$ show the amperometric currents vs. time of the $\mathrm{ZnO}-\mathrm{Zn}_{2} \mathrm{SnO}_{4}-\mathrm{SnO}_{2} / \mathrm{Gr} / \mathrm{CPE}$ for the determination of AA, AC and Caf, respectively. The $\mathrm{ZnO}-\mathrm{Zn}_{2} \mathrm{SnO}_{4}-\mathrm{SnO}_{2} / \mathrm{Gr} / \mathrm{CPE}$ demonstrates a linear response to $\mathrm{AA}, \mathrm{AC}$ and $\mathrm{Caf}$ in the concentration range of $0.013-16,0.008-12$ and $0.01-14 \mu \mathrm{M}$ with equations of $I p a=4.5093 \mathrm{C}+0.9019\left(\mathrm{R}^{2}=0.9985\right)$, Ipa $=5.6321 \mathrm{C}+1.0919\left(\mathrm{R}^{2}=0.9988\right)$ and Ipa $=$ $5.3442 \mathrm{C}+1.1917\left(\mathrm{R}^{2}=0.9984\right)$, respectively. Based on $\mathrm{S} / \mathrm{N}=3$, the DLs were determined to be $6.28,3.64$ and $3.85 \mathrm{nM}$ for $\mathrm{AA}, \mathrm{AC}$ and $\mathrm{Caf}$, respectively.

In another experiment, the simultaneous determination of AA, AC and, Caf was examined at the optimal condition. Good linearity of the oxidation peak current versus the concentrations of individual ana- lytes was observed according to the following equations:

$$
\begin{aligned}
& 0.021-8.06 \mu \mathrm{M} I_{p a}=4.7915 \mathrm{C}+0.5627 \mathrm{R}^{2}=0.9996 \\
& 8.06-120 \mu \mathrm{M} \quad I_{p a}=1.4768 \mathrm{C}+27.241 \mathrm{R}^{2}=0.9989 \\
& { }_{\mathrm{AC}}^{0.018-6.12 \mu \mathrm{M} I_{p a}=6.223 \mathrm{C}+0.744 \quad \mathrm{R}^{2}=0.9988} \\
& 6.12-85.3 \mu \mathrm{M} \quad I_{p a}=1.9592 \mathrm{C}+28.024 \mathrm{R}^{2}=0.9989 \quad \text { (10) } \\
& \text { Caf } \\
& 0.02-7.46 \mu \mathrm{M} \quad I_{p a}=5.7329 \mathrm{C}+0.5899 \mathrm{R}^{2}=0.9988 \\
& \text { 7.46-97.51 } \mu \mathrm{M} I_{p a}=1.806 \mathrm{C}+28.849 \quad \mathrm{R}^{2}=0.999
\end{aligned}
$$

The DLs for AA, AC and, Caf in the simultaneous detection were calculated to be 8.94, 6.66 and, 7.09 $\mathrm{nM}$, respectively. Also, a comparison between the slope of the equations in individual and, simultaneous determination for each species shows that the slopes are approximately equal, showing that the three analytes do not have any interference in the
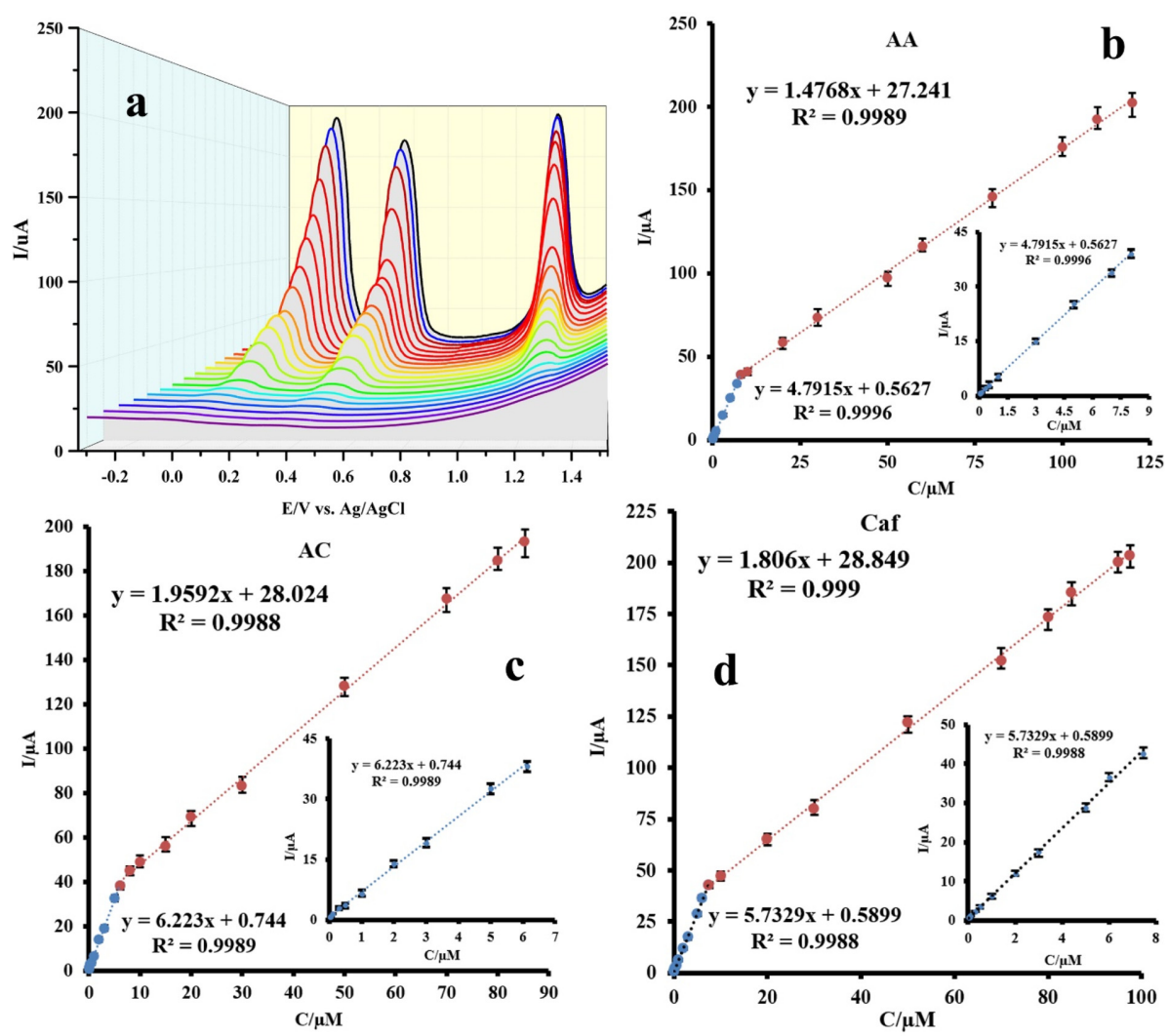

Fig. 6. (a) $3 \mathrm{D}$ DPVs at $\mathrm{ZnO}-\mathrm{Zn}_{2} \mathrm{SnO}_{4}-\mathrm{SnO}_{2} / \mathrm{Gr} / \mathrm{CPE}$ in $\mathrm{B}-\mathrm{R}$ buffer solution $\mathrm{pH}=7.2$ for simultaneous determination of $\mathrm{AA}$, $\mathrm{AC}$ and Caf; Calibration plots for (b) AA, (c) AC and (d) Caf, $\mathrm{n}=5$. 
determination of each other.

The two linear regions in calibration curves and the higher slope of the first linear range than that of the second region may be ascribed to two reasons. First: the saturation of the surface of the modified electrode with the target molecules. This behavior decrement the sensitivity of the electrochemical sensor (slope of calibration curve) in the second linear region of the calibration curve maybe owning to the formation of an analyte sub-monolayer in the first range of the calibration curve and formation of a monolayer in the second range. Second: This discrepancy in slopes was due to the different activities of the electrode surface with low and high concentrations of the analytes. Due to the high number of active sites (compared to the total number of the analyte mole- cules) in the electrode surface in the lower concentration of the analytes, the slope of the first linear region of the calibration curve was high. While in the higher concentration of the analytes, due to decreasing active sites, the slope of the second linear region of the calibration curve decreased [67-70].

\subsection{Interference and stability studies}

The effect of some potentially interfering species on the detection of $1 \mu \mathrm{M}$ AA, AC and Caf at $\mathrm{ZnO}$ $\mathrm{Zn}_{2} \mathrm{SnO}_{4}-\mathrm{SnO}_{2} / \mathrm{Gr} / \mathrm{CPE}$ was examined in detail at $\mathrm{pH}=7.2$. The tolerance limits were taken as the maximum amount of the foreign ions and molecules, which lead to an about $\pm 5 \%$ relative error in the current of measurements. The obtained data indicated that even 1000-fold of ions such as $\mathrm{Li}^{+}, \mathrm{Na}^{+}, \mathrm{K}^{+}, \mathrm{Cl}^{-}$,
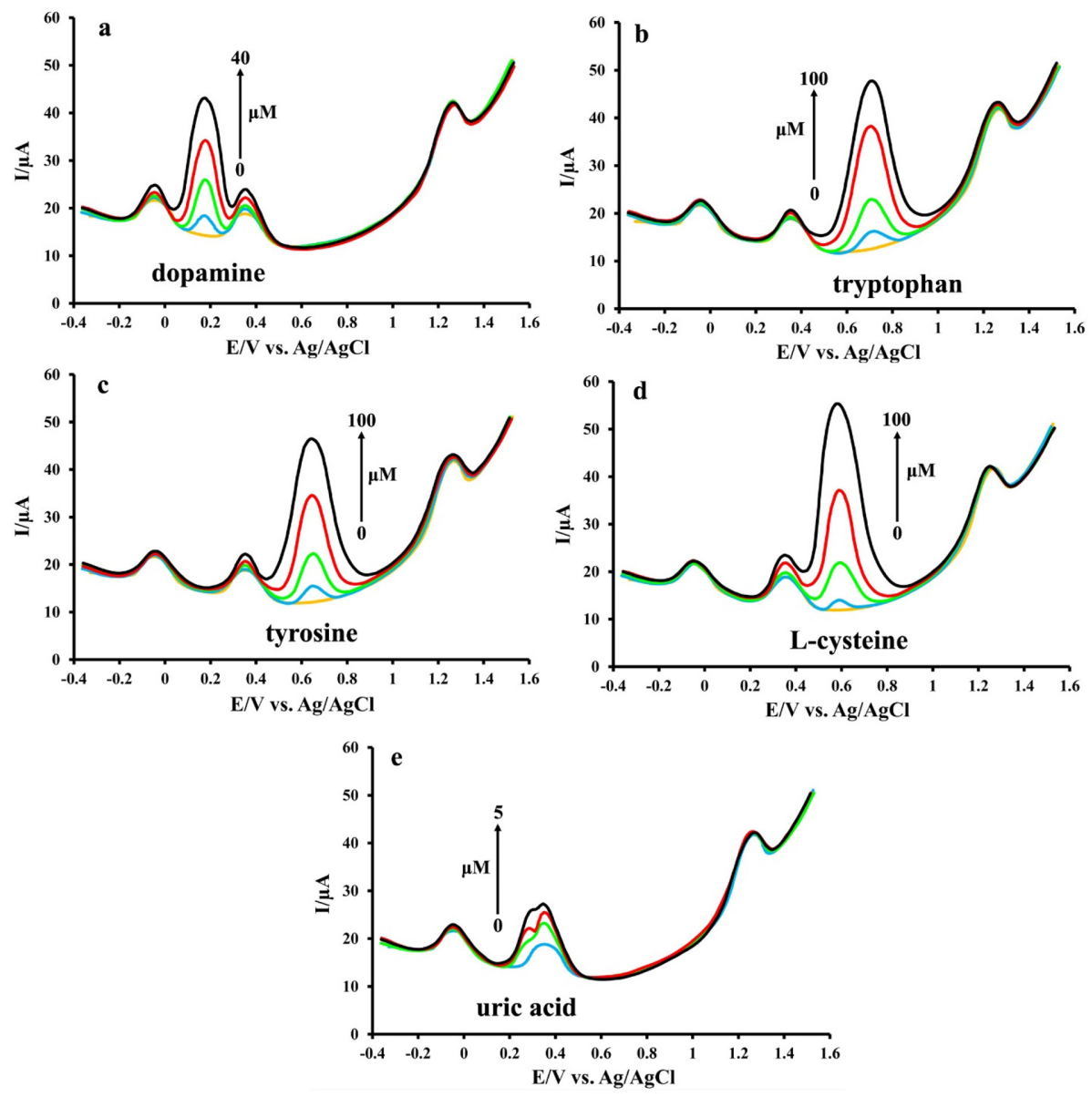

Fig. 7. DPVs at $\mathrm{ZnO}-\mathrm{Zn}_{2} \mathrm{SnO}_{4}-\mathrm{SnO}_{2} / \mathrm{Gr} / \mathrm{CPE}$ in $\mathrm{B}-\mathrm{R}$ buffer solution $\mathrm{pH}=7.2$ for $1.0 \mu \mathrm{M} \mathrm{AA}$, AC and Caf in the present of various concentration of (a) dopamine, (b) tryptophan, (c) tyrosine, (d) L-cysteine, (e) uric acid. 
$\mathrm{Ca}^{2+}, \mathrm{SO}_{4}{ }^{2-}, \mathrm{CO}_{3}{ }^{2-}, \mathrm{ClO}^{4-}$ and $\mathrm{HCO}_{3}{ }^{2-}$ has almost no effect on the response of the electrode. Also, 350-fold of fructose, lactose, glucose, 280-fold L-cysteine, tryptophan, tyrosine, urea, thiourea and 80 -fold of dopamine and 4-fold of uric acid did not change the response of the electrode for determination of AA, $\mathrm{AC}$ and $\mathrm{Caf}$ more than $5 \%$. Moreover, in the presence of the interfering species, no significant shift in the peak potentials was observed. The Fig. 7 represents the effect of some mentioned interfering species. Therefore, the $\mathrm{ZnO}-\mathrm{Zn}_{2} \mathrm{SnO}_{4}-\mathrm{SnO}_{2} / \mathrm{Gr} / \mathrm{CPE}$ can be considered as a well-modified sensor for the determination of AA, AC and, Caf in aqueous media.

The anodic peak currents of $1 \mu \mathrm{M}$ AA, AC and Caf at $\mathrm{ZnO}-\mathrm{Zn}_{2} \mathrm{SnO}_{4}-\mathrm{SnO}_{2} / \mathrm{Gr} / \mathrm{CPE}$ were almost unchanged (less than $5 \%$ reduction) when the electrode was stored in ambient temperature for 12 days.

\subsection{Real samples analysis}

The presented method was validated to determine the AA, AC and, Caf amount in different urine and serum samples in optimized condition by DPV technique, and the obtained results are represented in Table 1. The recoveries of the spiked samples calculated to be in the range of $95.8 \%$ to $104.06 \%$. The results confirm that the $\mathrm{ZnO}-\mathrm{Zn}_{2} \mathrm{SnO}_{4}-\mathrm{SnO}_{2} / \mathrm{Gr} / \mathrm{CPE}$ is very reliable, selective and sensitive to determine of AA, AC and, Caf levels in biological samples.

\section{Conclusions}

To sum up, a $\mathrm{ZnO}-\mathrm{Zn}_{2} \mathrm{SnO}_{4}-\mathrm{SnO}_{2} / \mathrm{Gr}$ nanocomposite was synthesisied for the individual and simultaneous electrochemical monitoring of AA, AC and Caf in two real samples with different matrices. The electrochemical investigations showed that $\mathrm{ZnO}$ $\mathrm{Zn}_{2} \mathrm{SnO}_{4}-\mathrm{SnO}_{2} / \mathrm{Gr}$ nanocomposite has high electrical conductivity; thus, it can be considered as a good candidate for using in the electrochemical application. The electro-oxidation of the three analytes is dependent on solution $\mathrm{pH}$, and it was found that two electrons and two protons are involved in the oxidation of $\mathrm{AA}$ and, $\mathrm{AC}$, and four electrons and four protons take part in the reaction of $\mathrm{Caf}$ at the surface of $\mathrm{ZnO}-\mathrm{Zn}_{2} \mathrm{SnO}_{4}-\mathrm{SnO}_{2} / \mathrm{Gr} / \mathrm{CPE}$. The $\mathrm{ZnO}-\mathrm{Zn}_{2} \mathrm{SnO}_{4}-$ $\mathrm{SnO}_{2} / \mathrm{Gr} / \mathrm{CPE}$ represents a desirable electrochemical response for determination of $\mathrm{AA}, \mathrm{AC}$ and $\mathrm{Caf}$ with the wide linear range of AA: 0.021-8.06 and 8.06$120 \mu \mathrm{M}, \mathrm{AC}: 0.018-6.12$ and $6.12-85.3 \mu \mathrm{M}$, Caf:
Table 1. Determination of $\mathrm{AA}, \mathrm{AC}$ and $\mathrm{Caf}$ in Urine and serum samples $(n=5)$.

\begin{tabular}{|c|c|c|c|c|c|}
\hline Sample & Analyte & $\begin{array}{c}\text { Added } \\
(\mu \mathrm{M})\end{array}$ & $\begin{array}{c}\text { Found } \\
(\mu \mathrm{M})\end{array}$ & $\begin{array}{c}\text { Recovery } \\
(\%)\end{array}$ & RSD\% \\
\hline \multirow{9}{*}{ Urine 1} & \multirow{3}{*}{ AA } & 0.00 & 0.00 & - & - \\
\hline & & 5.00 & 5.09 & 101.8 & 2.8 \\
\hline & & 50.00 & 49.12 & 98.24 & 3.1 \\
\hline & \multirow{3}{*}{$\mathrm{AC}$} & 0.00 & 0.00 & - & - \\
\hline & & 5.00 & 4.87 & 97.4 & 2.9 \\
\hline & & 50.00 & 51.04 & 102.08 & 3.4 \\
\hline & \multirow{3}{*}{ Caf } & 0.00 & 0.85 & - & 2.9 \\
\hline & & 5.00 & 5.96 & 102.2 & 3.0 \\
\hline & & 50.00 & 52.13 & 102.56 & 3.1 \\
\hline \multirow{9}{*}{ Urine 2} & \multirow{3}{*}{ AA } & 0.00 & 0.00 & - & - \\
\hline & & 5.00 & 4.79 & 95.8 & 2.6 \\
\hline & & 50.00 & 50.88 & 101.76 & 2.8 \\
\hline & \multirow{3}{*}{$\mathrm{AC}$} & 0.00 & 0.00 & - & - \\
\hline & & 5.00 & 5.16 & 103.2 & 3.1 \\
\hline & & 50.00 & 50.24 & 100.48 & 3.5 \\
\hline & \multirow{3}{*}{ Caf } & 0.00 & 0.49 & - & 2.9 \\
\hline & & 5.00 & 5.57 & 101.6 & 2.8 \\
\hline & & 50.00 & 49.99 & 99.0 & 3.4 \\
\hline \multirow{9}{*}{ Serum 1} & \multirow{3}{*}{ AA } & 0.00 & 0.00 & - & - \\
\hline & & 5.00 & 5.14 & 102.8 & 3.1 \\
\hline & & 50.00 & 52.03 & 104.06 & 3.0 \\
\hline & \multirow{3}{*}{$\mathrm{AC}$} & 0.00 & 0.00 & - & - \\
\hline & & 5.00 & 5.11 & 102.2 & 2.9 \\
\hline & & 50.00 & 48.86 & 97.72 & 3.1 \\
\hline & \multirow{3}{*}{$\mathrm{Caf}$} & 0.00 & 0.00 & - & - \\
\hline & & 5.00 & 5.15 & 102.3 & 2.6 \\
\hline & & 50.00 & 51.06 & 102.12 & 2.8 \\
\hline \multirow{9}{*}{ Serum 1} & \multirow{3}{*}{ AA } & 0.00 & 4.57 & - & 3.1 \\
\hline & & 5.00 & 9.76 & 103.8 & 2.9 \\
\hline & & 50.00 & 54.32 & 99.5 & 3.3 \\
\hline & \multirow{3}{*}{$\mathrm{AC}$} & 0.00 & 0.00 & - & - \\
\hline & & 5.00 & 5.12 & 102.4 & 2.7 \\
\hline & & 50.00 & 49.27 & 98.54 & 2.9 \\
\hline & \multirow{3}{*}{$\mathrm{Caf}$} & 0.00 & 12.28 & - & 2.9 \\
\hline & & 5.00 & 17.12 & 96.8 & 3.2 \\
\hline & & 50.00 & 63.01 & 101.46 & 3.4 \\
\hline
\end{tabular}

0.02-7.46 and 7.46-97.51 $\mu \mathrm{M}$, and the DLs were calculated to be 8.94, 6.66 and $7.09 \mathrm{nM}$, respectively. The comparison of the presented method with some previous literature methods for the determination of AA, AC and Caf was listed in Table 2. These data show that the linear ranges and DLs of $\mathrm{ZnO}$ $\mathrm{Zn}_{2} \mathrm{SnO}_{4}-\mathrm{SnO}_{2} / \mathrm{Gr} / \mathrm{CPE}$ for determination of $\mathrm{AA}, \mathrm{AC}$ and, Caf were comparable with those of other elec- 
Table 2. Comparison of the detection limits and linear ranges of the presented method with other electrochemical methods for the determination of AA, AC and Caf.

\begin{tabular}{|c|c|c|c|c|c|c|c|c|}
\hline \multirow{2}{*}{ Electrode } & \multirow{2}{*}{ Method } & \multicolumn{3}{|c|}{ Linear range $(\mu \mathrm{M})$} & \multicolumn{3}{|c|}{ Detection limit $(\mu \mathrm{M})$} & \multirow{2}{*}{ - Refs. } \\
\hline & & $\mathrm{AC}$ & $\mathrm{Caf}$ & AA & $\mathrm{AC}$ & Caf & AA & \\
\hline PSi-Ag/GCE ${ }^{1}$ & Amperometry & - & - & $20-600$ & - & - & 0.83 & {$[71]$} \\
\hline $\mathrm{PNBMGCE}^{2}$ & DPV & $0.2-16.2$ & $0.8-20$ & - & 0.08 & 0.1 & - & {$[72]$} \\
\hline MWCNT-Polyhis/GCE ${ }^{3}$ & DPV & $0.25-10$ & - & $25-2500$ & 0.032 & - & 0.76 & [73] \\
\hline $\mathrm{MnFe}_{2} \mathrm{O}_{4} @ \mathrm{CNT}-\mathrm{N} / \mathrm{GCE}^{4}$ & SWV & $1-1000$ & $1-1100$ & $2-100$ & 0.083 & 0.83 & 1.8 & {$[74]$} \\
\hline MWCNT/GCE 5 & SWV & - & $10-500$ & $10-500$ & - & 0.00352 & 0.01 & {$[75]$} \\
\hline SWCNT/CCE ${ }^{6}$ & DPV & $0.2-150$ & - & $5.00-700$ & 0.12 & - & 3.00 & {$[76]$} \\
\hline $\mathrm{CuO}-\mathrm{Gr} / \mathrm{CPE}^{7}$ & DPV & $0.025-5.30$ & $0.025-5.30$ & $0.025-5.30$ & 0.008 & 0.010 & 0.011 & [4] \\
\hline ISSM-CNT-PE $^{8}$ & DPV & $0.291-62.7$ & $0.291-62.7$ & - & 0.0258 & 0.0883 & - & [77] \\
\hline poly(AHNSA)/GCE ${ }^{9}$ & SWV & $10-125$ & $10-125$ & - & 0.45 & 0.79 & - & [78] \\
\hline $\begin{array}{l}\text { poly(Alizarin Violet 3B) } \\
\text { /MWCNT-GR/GCE }\end{array}$ & DPV & $0.2-100$ & $1-120$ & - & 0.01 & 0.02 & - & [79] \\
\hline GCE & DPV & $0-0.36$ & $0-0.26$ & $0-0.2$ & 0.048 & 0.043 & 0.05 & {$[10]$} \\
\hline $\mathrm{SnS} / \mathrm{TiO}_{2} @ \mathrm{GO} / \mathrm{GCE}$ & DPV & $0.0098-280$ & $0.0166-333$ & - & 0.0075 & 0.0044 & - & {$[41]$} \\
\hline $\mathrm{CoFe}_{2} \mathrm{O}_{4} / \mathrm{GCE}$ & DPV & $0.2-4.4$ & $0.2-4.4$ & $0.2-4.4$ & 0.267 & 0.313 & 0.226 & {$[40]$} \\
\hline $\mathrm{Pt}-\mathrm{GR} / \mathrm{GCE}$ & DPV & - & $90-380$ & - & - & 0.1129 & - & {$[42]$} \\
\hline $\mathrm{M} 221-\mathrm{Fe}_{3} \mathrm{O}_{4} / \mathrm{GCE}^{10}$ & DPV & $50-2000$ & $50-900$ & - & 16 & 23 & - & [43] \\
\hline \multirow[t]{2}{*}{$\mathrm{ZnO}-\mathrm{Zn}_{2} \mathrm{SnO}_{4}-\mathrm{SnO}_{2} / \mathrm{Gr} / \mathrm{CPE}$} & DPV & $\begin{array}{c}0.018-6.12 \\
6.12-85.3\end{array}$ & $\begin{array}{c}0.02-7.46 \\
7.46-97.51\end{array}$ & $\begin{array}{c}0.021-8.06 \\
8.06-120\end{array}$ & 0.00666 & 0.00709 & 0.00894 & \multirow{2}{*}{$\begin{array}{l}\text { This } \\
\text { work }\end{array}$} \\
\hline & Amperometry & $0.008-12$ & $0.01-14$ & $0.013-16$ & 0.00364 & 0.00385 & 0.00628 & \\
\hline
\end{tabular}

1 Silver nanoparticles decorated porous silicon glassy carbon electrode

2 Poly (Nile blue) modified glassy carbon electrode

3 Multi-wall carbon nanotubes dispersed in polyhistidine glassy carbon electrode

$4 \mathrm{~N}$-doped carbon nanotubes functionalized with $\mathrm{MnFe}_{2} \mathrm{O}_{4}$ nanoparticles glassy carbon electrode

5 Multiwall carbon nanotube modified glassy carbon electrode

6 Single-walled carbon nanotube-modified carbon ceramic electrode

$7 \mathrm{CuO}$-graphene nanocomposite carbon paste electrode

8 In situ surfactant-modified multiwalled carbon nanotube paste electrode

9 Poly(4-amino-3-hydroxynaphthalene sulfonic acid)-modified glassy carbon electrode

10 MIP membrane from cassava starch $-\mathrm{Fe}_{3} \mathrm{O}_{4}$ modified glassy carbon electrode

trochemical sensors and the DLs obtained for AC and AA were the lowest by the proposed method, as shown in Table 2. Moreover, $\mathrm{ZnO}-\mathrm{Zn}_{2} \mathrm{SnO}_{4}-\mathrm{SnO}_{2} /$ $\mathrm{Gr} / \mathrm{CPE}$ operates well in the determine of $\mathrm{AA}, \mathrm{AC}$ and, $\mathrm{Caf}$ in urine and, serum samples with excellent accuracy and precision.

\section{References}

[1] Z. Liew, B. Ritz, C. Rebordosa, P.-C. Lee, J. Olsen, JAMA pediatrics, 2014, 168(4), 313-320.

[2] J.D. Barker, D.J. de CARLE, S. Anuras, Ann. Intern. Med, 1977, 87(3), 299-301.

[3] A. Zwyghuizen-Doorenbos, T.A. Roehrs, L. Lipschutz,
V. Timms, T. Roth, Psychopharmacology, 1990, 100(1), 36-39.

[4] Z.M. Khoshhesab, RSC Adv., 2015, 5(115), 9514095148.

[5] B.C. Lourenção, R.A. Medeiros, R.C. Rocha-Filho, L.H. Mazo, O. Fatibello-Filho, Talanta, 2009, 78(3), 748-752.

[6] Y. Gao, H. Wang, L. Guo, J. Electroanal. Chem., 2013, 706, 7-12.

[7] O. Cauli, M. Morelli, Behav. Pharmacol., 2005, 16(2), 63-77.

[8] S. Duffy, N. Gokce, M. Holbrook, A. Huang, B. Frei, J.F. Keaney Jr, J.A. Vita, The lancet, 1999, 354(9195), 2048-2049.

[9] N. Smirnoff, Free Radical Biol. Med., 2018, 122, 116129. 
[10] O.-W. Lau, S.-F. Luk, Y.-M., Analyst, 1989, 114(9), 1047-1051.

[11] N.H. Phong, T.T.T. Toan, M.X. Tinh, T.N. Tuyen, T.X. Mau, D.Q. Khieu, J. Nanomater, 2018, 5348016.

[12] L. Suntornsuk, W. Gritsanapun, S. Nilkamhank, A. Paochom, J. Pharm. Biomed. Anal., 2002, 28(5), 849855.

[13] W. Zeng, F. Martinuzzi, A. MacGregor, J. Pharm. Biomed. Anal., 2005, 36(5), 1107-1111.

[14] M. Romeu-Nadal, S. Morera-Pons, A. Castellote, M. Lopez-Sabater, J. Chromatogr. B, 2006, 830(1), 41-46.

[15] G. Burgot, F. Auffret, J.-L. Burgot, Anal. Chim. Acta, 1997, 343(1-2), 125-128.

[16] R. Săndulescu, S. Mirel, R. Oprean, J. Pharm. Biomed. Anal., 2000, 23(1), 77-87.

[17] E. McEvoy, S. Donegan, J. Power, K. Altria, J. Pharm. Biomed. Anal., 2007, 44(1), 137-143.

[18] S. Mayanna, B. Jayaram, Analyst, 1981, 106(1263), 729-732.

[19] N. Ishler, T. Finucane, E. Borker, Anal. Chem., 1948, 20(12), 1162-1166.

[20] A.R. Khorrami, A. Rashidpur, Anal. Chim. Acta, 2012, $727,20-25$.

[21] A. Babaei, A.R. Taheri, Sens. Actuators, B, 2013, 176, 543-551.

[22] M. Hasanzadeh, N. Shadjou, E. Omidinia, J. Neurosci. Methods, 2013, 219(1), 52-60.

[23] H. Bagheri, A. Hajian, M. Rezaei, A. Shirzadmehr, J. Hazard. Mater., 2017, 324, 762-772.

[24] H. Bagheri, A. Shirzadmehr, M. Rezaei, H. Khoshsafar, Ionics, 2018, 24(3), 833-843.

[25] M.M. Rahman, J.-J. Lee, J. Electrochem. Sci. Technol., 2019, 10, 185-195.

[26] M.M. Rahman, X.-b. Li, Y.-D. Jeon, H.-J. Lee, S.J. Lee, J.-J. Lee, J. Electrochem. Sci. Technol., 2012, 3(2), 9094.

[27] X.-B. Li, M.M. Rahman, G.-R. Xu, J.-J. Lee, Electrochim. Acta, 2015, 173, 440-447.

[28] J. Yu, T.H. Kim, J. Electrochem. Sci. Technol., 2017, 8(4), 274-281.

[29] K. Ghanbari, S. Bonyadi, J. Electrochem. Sci. Technol., 2020, 11(1), 68-83.

[30] P. Viswanathan, R. Ramaraj, Sens. Actuators, B, 2018, 270, 56-63.

[31] P. Viswanathan, S. Manivannan, R. Ramaraj, RSC Adv., 2015, 5(67), 54735-54741.

[32] M. Sobaszek, K. Siuzdak, J. Ryl, R. Bogdanowicz, G.M. Swain, Sens. Actuators, B, 2020, 306, 127592.

[33] á. Gorton, Electroanalysis, 1995, 7(1), 23-45.

[34] T. Alizadeh, M. Akhoundian, Electrochim. acta, 2010, 55(20), 5867-5873.

[35] X.-M. Miao, R. Yuan, Y.-Q. Chai, Y.-T. Shi, Y.-Y. Yuan, J. Electroanal. Chem., 2008, 612(2), 157-163.

[36] A. Salimi, H. Mamkhezri, R. Hallaj, S. Soltanian, Sens. Actuators, B, 2008, 129(1), 246-254.

[37] M.M. Rahman, J.-J. Lee, J. Electrochem. Sci. Technol,
2019, 10, 185-195.

[38] M.M. Rahman, N.S. Lopa, M.J. Ju, J.-J. Lee, J. Electroanal. Chem., 2017, 792, 54-60.

[39] D. Liu, M.M. Rahman, C. Ge, J. Kim, J.-J. Lee, New J. Chem., 2017, 41(24), 15458-15465.

[40] P.T.K. Thu, N.D. Trinh, N.T.V. Hoan, D.X. Du, T.X. Mau, V.H. Trung, N.H. Phong, T.T.T. Toan, D.Q. Khieu, J. Mater. Sci.: Mater. Electron., 2019, 30(18), 1724517261.

[41] E. Murugan, K. Kumar, Anal. Chem., 2019, 91(9), $5667-5676$.

[42] J. Qiao, L. Zhang, S. Gao, N. Li, Appl. Biochem. Biotechnol., 2020, 190(2), 529-539.

[43] A. Mulyasuryani, R.T. Tjahjanto, R.a. Andawiyah, Chemosensors, 2019, 7(4), 49.

[44] N. Tripathy, R. Ahmad, H. Kuk, D.H. Lee, Y.-B. Hahn, G. Khang, J. Photochem. Photobiol., B, 2016, 161, 312317.

[45] S. Wu, H. Cao, S. Yin, X. Liu, X. Zhang, J. Phys. Chem. C, 2009, 113(41), 17893-17898.

[46] P. Junploy, S. Thongtem, T. Thongtem, A. Phuruangrat, Superlattices Microstruct., 2014, 74, 173-183.

[47] M. Chitra, K. Uthayarani, N. Rajasekaran, N. Neelakandeswari, E. Girija, P.D. Pathinettam, Nanosyst.: Phys., Chem., Math., 2016, 7(4), 707-710.

[48] U. Bhat, S. Meti, Graphene as Energy Storage Material for Supercapacitors, 2020, 64, 181.

[49] C.H.A. Tsang, H. Huang, J. Xuan, H. Wang, D. Leung, Renewable Sustainable Energy Rev., 2020, 120, 109656.

[50] B. Wang, T. Ruan, Y. Chen, F. Jin, L. Peng, Y. Zhou, D. Wang, S. Dou, Energy Storage Mater, 2020, 24, $22-51$.

[51] L.u. Švorc, K. Cinková, J. Sochr, M. Vojs, P. Michniak, M. Marton, J. Electroanal. Chem., 2014, 728, 86-93.

[52] B. Liu, X. Ouyang, Y. Ding, L. Luo, D. Xu, Y. Ning, Talanta, 2016, 146, 114-121.

[53] H. Zeinali, H. Bagheri, Z. Monsef-Khoshhesab, H. Khoshsafar, A. Hajian, Mater. Sci. Eng. C, 2017, 71, 386-394.

[54] X.L. Cheng, H. Zhao, L.H. Huo, S. Gao, J.G. Zhao, Sens. Actuators, B, 2004, 102(2), 248-252.

[55] L.M. Yu, X.H. Fan, J.Y. Shui, L. Cao, W. Yan, $A d v$. Mater. Res., 2012, 532, 70-73.

[56] Q. Zhou, L. Yang, G. Wang, Y. Yang, Biosens. Bioelectron., 2013, 49, 25-31.

[57] R.K. Thareja, S. Shukla, Appl. Surf. Sci., 2007, 253(22), 8889-8895.

[58] M. Masjedi-Arani, M. Salavati-Niasari, J. Mol. Liq., 2017, 248, 197-204.

[59] M. Naghizadeh, M.A. Taher, A.-M. Heliyon, 2019, 5(11), e02870.

[60] M. Krishna, S. Komarneni, Ceram. Int., 2009, 35(8), 3375-3379.

[61] K. Handore, S. Bhavsar, A. Horne, P. Chhattise, K. Mohite, J. Ambekar, N. Pande, V. Chabukswar, J. Macromol. Sci., Part A, 2014, 51(12), 941-947.

[62] C. Liangyuan, B. Shouli, Z. Guojun, L. Dianqing, C. 
Aifan, C.C. Liu, Sens. Actuators, B, 2008, 134(2), 360366.

[63] T. Jia, J. Zhao, F. Fu, Z. Deng, W. Wang, Z. Fu, F. Meng, Int. J. Photoenergy, 2014, 197824.

[64] R. Dharmadasa, A.A. Tahir, K.G.U. Wijayantha, J. Am. Ceram. Soc., 2011, 94(10), 3540-3546.

[65] M. Amare, S. Admassie, Talanta, 2012, 93, 122-128.

[66] F. Tadayon, Z. Sepehri, RSC Adv., 2015, 5(8), 6556065568.

[67] E.S. Gomes, F.R.F. Leite, B.R.L. Ferraz, H.A.J.L. Mourão, A.R. Malagutti, J. Pharm. Anal., 2019, 9(5), 347-357.

[68] H. Rao, Z. Lu, H. Ge, X. Liu, B. Chen, P. Zou, X. Wang, H. He, X. Zeng, Y. Wang, Microchim. Acta, 2017, 184(1), 261-269.

[69] A. Motaharian, F. Motaharian, K. Abnous, M.R.M. Hosseini, M. Hassanzadeh-Khayyat, Anal. Bioanal. Chem., 2016, 408(24), 6769-6779.

[70] B. Rezaei, S. Foroughi-Dehnavi, A.A. Ensafi, Ionics, 2015, 21(10), 2969-2980.

[71] F.A. Harraz, M. Faisal, A.E. Al-Salami, A.M. El-Toni,
A.A. Almadiy, S.A. Al-Sayari, M.S. Al-Assiri, Mater. Lett., 2019, 234, 96-100.

[72] S. Chitravathi, N. Munichandraiah, J. Electroanal. Chem., 2016, 764, 93-103.

[73] P.R. Dalmasso, M.L. Pedano, G.A. Rivas, Sens. Actuators, B, 2012, 173, 732-736.

[74] D.M. Fernandes, N. Silva, C. Pereira, C. Moura, J.M.C.S. Magalhães, B. Bachiller-Baeza, I. RodríguezRamos, A. Guerrero-Ruiz, C. Delerue-Matos, C. Freire, Sens. Actuators, B, 2015, 218, 128-136.

[75] V.K. Gupta, A.K. Jain, S.K. Shoora, Electrochim. Acta, 2013, 93, 248-253.

[76] B. Habibi, M. Jahanbakhshi, M.H. Pournaghi-Azar, Anal. Biochem., 2011, 411, 167-175.

[77] B.J. Sanghavi, A.K. Srivastava, Electrochim. Acta, 2010, 55(28), 8638-8648.

[78] M. Tefera, A. Geto, M. Tessema, S. Admassie, Food Chem., 2016, 210, 156-162.

[79] Y. Wang, T. Wu, C.-y. Bi, Microchim. Acta, 2016, 183(2), 731-739. 